\title{
ENROLMENT PROJECTION AND COST IMPLICATION OF UNIVERSAL BASIC EDUCATION IN NIGERIA
}

\author{
IGBINEWEKA, V. O. AND Dr. ADEYEMI, J. K.
}

\begin{abstract}
The paper evaluated implementation of the Universal Basic Education (UBE) scheme for the first ten years of implementation, 2002-2012. Pupil enrolment for the period was projected and the cost implication of implementing the scheme estimated to guide government assess its ability to continue the implementation of the scheme, review its strategies of implementation or even abandon the scheme like the previous experiment with $U B E$ scheme. The two research questions raised for the study were answered using documentary analysis, models and descriptive statistics. The result of analysis showed that over 46 million children would have been enrolled in schools and N52.9 billion spent annually if the scheme had been effectively implemented. The sight of basic school-going aged children at motor parks, markets and hawking along major streets during school hours suggests that the implementation of the scheme has not effective. It was therefore recommended among others that government should concentrate only on the supply and management of basic education in order to garner adequate funds to sustain its implementation and, allow private individuals and non-governmental organizations to supply and manage other levels of education.
\end{abstract}

\section{Introduction}

Education, a dynamic learning process transforms and builds in individuals an inherent capacity to acquire appropriate information, skills and competencies for survival in the society. This is the framework upon which development and continuity of the society hinges. The decimation of the world to a small village by the explosion in information technology has therefore, made the provision of education a responsibility that government can no longer treat with levity. This is because people that are not educated cannot meaningfully take part in the task of nation building. Besides, people's inability to participate makes survival in the society difficult in the short run and completely impossible in the long run as the society becomes more complex, formal and sophisticated.

To equip people therefore with the capacity to survive and contribute to the development of the society, the celebrated UN Declaration of 1948, calling on every member nation to provide universal basic education has become readily prescriptive to the problem of underdevelopment. According to Aghenta (2001), Adewole (2000), Omokhodion (2000), Federal Government of Nigeria (FGN, 2004) and unescro (2005) the provision of education is a prerequisite requirement for any society to develop. A review of available literature on universalisation of basic education reveals that countries all over the world are making frantic efforts to increase the supply of basic education. Ten years after the world conference on "Education for All" in Jomtien, Thailand in March, 1990, the World Education Forum under the auspices of UNESCO, UNICEF, UNOP, UNFPA and the World Bank, Governments and Non-Governmental Organisations in Dakar, Senegal, April 2000 has provided an opportunity to assess the achievements and failures of the "Jomtien Decade".

Global result of the assessment shows that out of over 900 million children expected to be enrolled in schools as at the end of the Jomtien decade only 681 million (or 75 percent) were 
actually in school. The other 219 million children (or 25 percent) have no access to school. Since ample evidence from South Korea, Malaysia, Mexico and the developed societies demonstrates that universalisation of education is associated with a wide range of indicators of well-being, including a nation's increased productivity and competitiveness as well as social and political progress, the task of expanding access according to Woldensohn (2000), Matsuura (2000) and Hinzen (2001) for all to be educated to facilitate development in the nooks and crannies of the emerging global village is an urgent responsibility for all. The prompt response by government and non-governmental organizations to this clarion call by launching campaigns to universalize the provision of education underscores growing awareness of the perception of education as instrument par excellence for effecting national development. Available information from the world conference shows that countries have set specific targets according to their situations and capabilities to provide at least basic education for all. This of course, provided the motivation for the recent launching of Universal Basic Education (UBE) scheme more than a decade ago in Nigeria. For education to facilitate development therefore, the school (one of the valuable institutions established by society to educate its citizenry) has to be made accessible to all persons irrespective of age and circumstances of birth for the society to develop as practiced in developed nations like USA, Canada, Singapore etc.

The commencement of implementation of the scheme therefore in Nigeria to expand access to formal education at a time when governments all over the world are universalizing access to education is a step in the right direction. When the programme implementation commences, school attendance at the primary and junior secondary school levels is expected to be free and compulsory. There is no doubt that many Nigerian children will avail themselves of the opportunity and enroll in schools. Parents who had earlier parents at withdrew their children from school as a result of poverty will be happy and take advantage of the free component of the UBE scheme to send their children back to school. The consequence of this is that literacy rate within the first few years of implementation is likely to increase appreciably from its present 57 percent to a more meaningful benchmark critical for development.

However there is a fear that the cost of financing compulsory free education up to junior secondary school level may be so prohibitive that the UBE school programme like the previous experiment with Universal Primary Education (UPE) programme of 1976 may be abandoned few years after kick off. Money budgeted to fund UPE in the 1975-80 development plan period according to Aiyepeku (1989) was $\$ 500,000,000$ (for both current and capital expenditures) but by the end of the second year in the plan period, government had spent a total of $\$ 1.226$ billion. This shows that extra $\$ 729,000,000$ was spent by the government who believed in its ability to single-handedly fund the UPE scheme to achieve its laudable objectives. When it became practically impossible for the federal government to continue the funding of UPE, the funding was transferred to both state and Local government in January 1980. The scheme eventually collapsed as the State and Local government continuously expressed their inability to provide fund to sustain the programme that they did not initiate nor plan for. 
More than a decade of government experimenting with its capacity to implement the scheme, it has become imperative to project students enrolment and estimate its cost for the first 10 years of implementation of the scheme in Nigeria. The importance of this seeming retrospective projection cannot be over emphasized. Government therefore is expected to be equipped with critical information to evaluate implementation of the scheme since 2001 and decide either to sustain the scheme or review implementation strategies or even abandon the scheme. To do this, answers to the following research questions will guide the thrust of this paper.

1. What was the size of UBE school - going age population over the projection period, $2002-2011$ ?

2. What was the cost of making UBE free and compulsory for the plan period, 20022011 ?

\section{Methodology}

The UBE school-going age population (i.e children within 6-15 years age bracket was determined by using Spraque's Coefficient to extract the children from the 1991 total population census as officially published by National Population Commission (NPC, 1997) and thereafter projected with 2.83 percent official growth rate while actual enrolment figures were obtained from relevant records of the Universal basic Education Commission headquarters. As for cost projection, actual costs of capital and recurrent expenditures were obtained from appropriate records and projected with the assumption that unit costs will remain constant during the plan period. Comparing projected and actual enrolment the number of children expected to be compelled to attend school was ascertained with cost implications for additional teachers and facilities with the assumptions that: Population Enrolment growth rate will remain constant at $2.83 \%$ per annum; Parents/Guardians will be compelled by government to send all their children between 6-15 years to schools. Both primary and secondary school pupils use the same type of building and furniture. Cost of basic capital and recurrent expenditures were assumed to remain constant over the period under investigation. Occurrence of wastage in the forms of repetition and dropout in the school system during the same period, if any, were also assumed to be negligible and inconsequential. Adequate number of teachers, facilities and equipment promised by government at the eve of implementation of the scheme in 2001 have unfortunately not been provided as observed in several schools (Nwadiani, 2014). Similarly, Akpa (2014) has reported that established standards such school programme duration; class size studentteacher ratio, school calendar, teacher quality etc have also been compromised.

\section{UBE School-Going Age Population over the Projection Period, 2002-2011}

Unprecedented increase in enrolment of children between 6 and 15 years bracket have preceded the implementation of the scheme over the years. At the commencement of implementation in 2002 projected student enrolment had increased from 3,018,408 to 4,102,949. By the year 2003, two classes, primaries 1 and 2, that comprised 4,219,063 new entrants and 4,102,949 pupils in primary one the previous year respectively would have been enrolled in the UBE schools. Classrooms are expected to have correspondingly increased to 
accommodate the increasing number of children taking advantage of the free and compulsory components of the scheme. This pattern according to projection continued till the year 2010 when all the nine classes of UBE scheme would have been occupied with a total projected enrolment of 41,394,708. This is the year the maiden cohort was expected to transit from junior secondary school class three (3) to senior secondary school class one (1). From that year 2010, all the classes from primary one to junior secondary school class three would have been occupied by UBE children as shown in figure 1 . 


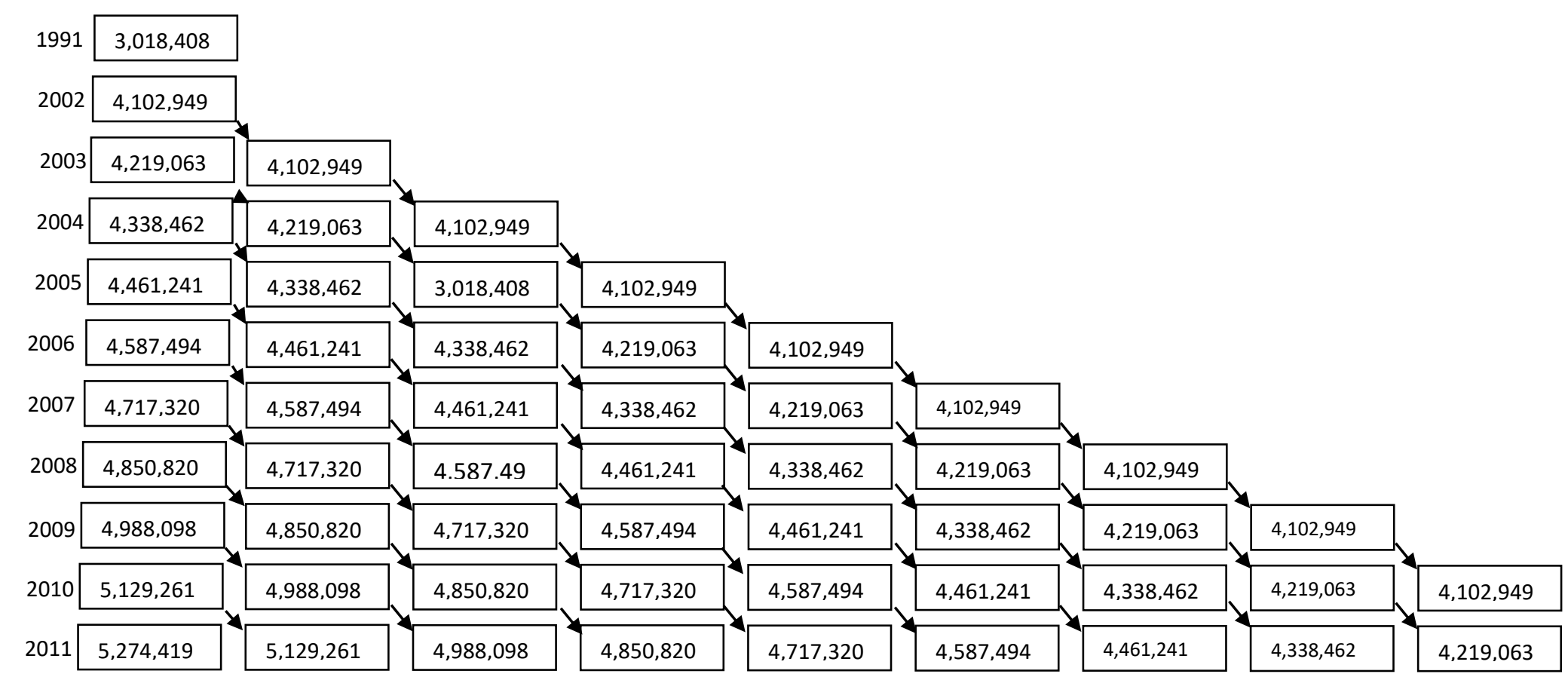

Figure1: Projected UBE School-going Age Population for Ten Years, 2002-2011

Note: 1991 Six-Year Olds were extracted from 1991 National Census using Sprague's Coefficient. Projection was based on $2.83 \%$ annual growth rate.

Source: Researchers' Computation 
Cost Implication of Making UBE Free and Compulsory for the Plan Period, 2002-2011

Making UBE free and compulsory has implications for additional fund to finance capital and recurrent school expenditures that will no doubt escalate. Except adequate funds are provided to match increasing enrolment of pupils, the UBE scheme like previous scheme (UPE, Free Education) is bound to fail. Since the present government has, however, avowed to correct the mistakes of the past by making adequate funds available for the implementation of free and compulsory school attendance policy, it is therefore imperative to know what the cost implication of such a laudable policy will be. To know the cost implication therefore, the costs of recurrent expenditures (Teachers' salary and non-teachers' salary) and capital expenditure (i.e additional classrooms, additional furniture and chalkboards) especially within the plan period are computed as shown in tables 1-4 below 
Table 1: Teachers' and Non-Teachers' Cost Estimates in UBE Schools for the Period, 2002-2011

\begin{tabular}{|c|c|c|c|c|c|c|c|c|c|}
\hline \multirow[t]{2}{*}{ Year } & \multirow[b]{2}{*}{$\begin{array}{l}\text { projected } \\
\text { UBE } \\
\text { School- } \\
\text { going } \\
\text { Children } \\
\text { expected } \\
\text { in schools }\end{array}$} & \multirow{2}{*}{$\begin{array}{l}\text { teachers } \\
\text { required } \\
\text { t } 1: 40\end{array}$} & \multirow{2}{*}{$\begin{array}{l}\text { available } \\
\text { teachers }\end{array}$} & \multirow{2}{*}{$\begin{array}{l}\text { extra } \\
\text { teachers }\end{array}$} & \multicolumn{3}{|c|}{ Cost implication at N401,223,29* (in N) } & \multirow{2}{*}{$\begin{array}{l}\text { non-teacher } \\
\text { cost (in N) }\end{array}$} & \multirow{2}{*}{$\begin{array}{l}\text { total recurr } \\
\operatorname{cost}(\text { in } N)\end{array}$} \\
\hline & & & & & $\begin{array}{l}\text { available } \\
\text { teachers }\end{array}$ & $\begin{array}{l}\text { extra } \\
\text { teachers }\end{array}$ & Total & & \\
\hline $2001 / 2002$ & $4,102,949$ & 102,573 & $429,075^{* *}$ & Nil & $17,215,488,320$ & Nil & $17,215,488,320$ & $4,303,872,080$ & $21,519,360$ \\
\hline $2002 / 2003$ & $8,322,012$ & 208,050 & 429,075 & Nil & $17,215,488,320$ & Nil & $17,215,488,320$ & $4,303,872,080$ & $21,519,360$ \\
\hline $2003 / 2004$ & $12,660,474$ & 316,511 & 429,075 & Nil & $17,215,488,320$ & Nil & $17,215,488,320$ & $4,303,872,080$ & $21,519,360$ \\
\hline $2004 / 2005$ & $17,121,715$ & 428,042 & 429,075 & 90,900 & $17,215,488,320$ & Nil & $17,215,488,320$ & $4,303,872,080$ & $21,519,360$ \\
\hline $2005 / 2006$ & $21,709,209$ & 524,730 & 429,075 & 113,655 & $17,215,488,320$ & $4,560,103,303$ & $21,775,591,623$ & $5,443,897,907$ & $27,219,489$ \\
\hline $2006 / 2007$ & $26,426,529$ & 660,663 & 542,730 & 117,933 & $21,775,591,623$ & $4,731,746,626$ & $26,507,338,249$ & $6,626,834,551$ & $33,134,235$ \\
\hline $2007 / 2008$ & $31,277,349$ & 781,933 & 660,663 & 121,270 & $26,507,338,249$ & $4,865,634,838$ & $31,372,973,087$ & $7,843,263,243$ & $39,216,216$ \\
\hline $2008 / 2009$ & $36,265,447$ & 906,636 & 781,933 & 124,703 & $31,372,973,087$ & $4,963,252,464$ & $36,335,225,551$ & $8,083,806,389$ & $45,419,031$ \\
\hline $2009 / 2010$ & $41,394,708$ & $1,034,867$ & 905,636 & 128,231 & $36,335,225,551$ & $5,185,048,699$ & $41,520,274,250$ & $9,380,068,560$ & $51,900,342$ \\
\hline $2010 / 2011$ & $46,669,127$ & $1,166,728$ & $1,034,861$ & 131,861 & $41,520,274,251$ & $5,290,570,424$ & $46,810,844,674$ & $11,702,711,166$ & $58,513,555$ \\
\hline \multicolumn{7}{|c|}{ Total } & $267,184,250,714$ & $66,296,050,156$ & $333,480,300$ \\
\hline
\end{tabular}

**Actual Number of Teachers available as at 2000 provided by UBE Commission, 2014

*Average annual salary per teacher. This was worked out by computing the mean of HATISS 6-15 where all teachers with a minimum qualification of NCE are expected to belong in the TSS salary structure.

Source (a) Researchers' Computation

(b) National Commission for Salary and Wages, Abuja, 2014

(c) Federal Ministry of Education, Abuja, 2014 
As shown in Table 1, additional 113655 teachers would have been required as from the year 2005/2006 school year when the number of UBE children occupied classes increased from 1 in 2001/2002 to 5. The cost of paying teachers' salary would have also will then increased from $\$ 17,215,488,320.00$ to $\$ 21,775,591,623.00$, and by $2009 / 2010$ school year when all the classes, primary 1 to JSS 3 would have been occupied, total recurrent cost would have skyrocketed from $\$ 21,519,360,400.00$ in $2001 / 2002$ to $\$ 51,900,342,810.00$. Further analysis of the cost implication of implementing the scheme for the period under investigation shows the average annual total recurrent cost for the ten year period to be $\$ 33,348,030,087.00$. Apart from the need for additional teachers during the period, the need for additional classrooms, instruction boards, furniture for both teachers and pupils will become inevitable as shown in table 2 below: 
Table 2: Additional Classrooms, Furniture and Instruction Boards for UBE Schools for the Period, 2002-2011

\begin{tabular}{|c|c|c|c|c|c|c|c|c|c|c|}
\hline \multirow[t]{2}{*}{ Year } & \multirow[b]{2}{*}{$\begin{array}{l}\text { Projected } \\
\text { UBE } \\
\text { School- } \\
\text { Going } \\
\text { Children } \\
\text { Expected } \\
\text { in Schools }\end{array}$} & \multicolumn{3}{|c|}{ Classrooms } & \multicolumn{4}{|c|}{ Furniture } & \multicolumn{2}{|c|}{ Instruction Board } \\
\hline & & $\begin{array}{l}\text { Required } \\
\text { at } 1: 40\end{array}$ & Available & Extra & Available & Extra & Available & Extra & Available & Extra \\
\hline $2001 / 2002$ & $4,102,949$ & 102,573 & $337,052 *$ & Nil & $429,075 * *$ & Nil & $20,590,000 * *$ & Nil & $337,052 * * * *$ & Nil \\
\hline $2004 / 2005$ & $17,121,715$ & 428,042 & 337,052 & 90,990 & 429,075 & Nil & $20,590,000$ & Nil & 337,052 & 90,990 \\
\hline $2005 / 2006$ & $21,709,209$ & 524,730 & 428,042 & 114,588 & 429,075 & 113,655 & $20,590,000$ & $1,119,209$ & 428,042 & 114,688 \\
\hline $2006 / 2007$ & $26,426,529$ & 660,663 & 542,730 & 117,933 & 524,730 & 117,933 & $21,709,209$ & $4,717,320$ & 542,730 & 117,933 \\
\hline $2007 / 2008$ & $31,277,349$ & 781,933 & 660,663 & 121,270 & 660,663 & 121,270 & $26,426,529$ & $4,850,820$ & 660,663 & 121,270 \\
\hline $2008 / 2009$ & $36,265,447$ & 906,636 & 781,933 & 124,703 & 781,933 & 123,703 & $31,277,349$ & $4,988,096$ & 781,933 & 124,703 \\
\hline
\end{tabular}

*Actual number of classrooms as at 2000/2001 school year

**Actual number of office tables/chairs for teachers as at 2000/2001 school year

***Actual number of classroom desks/chairs for pupils as at 2000/2001 school year

****Actual number of chalkboards as at 2000/2001 school year

Source: Researchers computation 
The table shows that 90,990 additional classrooms and chalkboards would have been needed at the beginning of 2004/2005 school year to adequately accommodate all the 17,121,715 UBE school age children expected to be in school by that year while additional $1,119,209$ pairs of tables/desks and 113,655 pairs of office tables/chairs would have been needed by the beginning of 2005/2006 school year for pupils and teachers respectively. And by the year 2010, additional classrooms; 129,231 office chairs/tables for teachers and; 5,129,261 chairs/desks for pupils would have been needed for the UBE school scheme to be fully operational. The cost implication of these additional school facilities for the period under investigation is shown in table 3 . 
Table 3: Cost of Additional Classrooms, Furnitures and Instruction Boards for UBE Schools for the Period, 2002-2011

\begin{tabular}{|c|c|c|c|c|c|c|c|c|c|}
\hline \multirow[t]{3}{*}{ Year } & \multicolumn{3}{|c|}{ Number of Additional Facilities } & \multicolumn{4}{|c|}{ Cost of Additional Facilities } & \multirow{2}{*}{\multicolumn{2}{|c|}{$\begin{array}{l}\text { Chalkboards at } \\
\text { N1,800*** }\end{array}$}} \\
\hline & \multirow[t]{2}{*}{ Classroom } & \multicolumn{2}{|c|}{ Furniture } & \multirow[t]{2}{*}{ Chalkboard } & \multirow{2}{*}{$\begin{array}{l}\text { Classrooms at } \\
\text { N1,701,119.72* }\end{array}$} & \multicolumn{2}{|l|}{ Furniture for } & & \\
\hline & & Teacher & Pupils & & & $\begin{array}{l}\text { Teachers at } \\
\mathrm{N5,100**}\end{array}$ & $\begin{array}{l}\text { Pupils at } \\
\text { N5,100 }\end{array}$ & & \\
\hline $2001 / 2002$ & Nil & Nil & Nil & Nil & Nil & - & - & - & - \\
\hline $2002 / 2003$ & Nil & Nil & Nil & Nil & Nil & - & - & - & - \\
\hline $2003 / 2004$ & Nil & Nil & Nil & Nil & Nil & - & - & - & - \\
\hline $2004 / 2005$ & 90,990 & Nil & Nil & 90,990 & $15,478,488,330$ & - & $5,459,400,000$ & $163,782,000$ & $21,101,67$ \\
\hline $2005 / 2006$ & 114,688 & 113,655 & $1,119,209$ & 114,688 & $19,509,801,840$ & $579,640,500$ & $6,881,280,000$ & $206,438,400$ & $27,187,16$ \\
\hline $2006 / 2007$ & 117,933 & 117,933 & $4,717,320$ & 117,933 & $20,051,809,890$ & $601,458,300$ & $7,075,980,000$ & $212,279,400$ & $27,951,5$ \\
\hline $2007 / 2008$ & 121,270 & 121,270 & $4,850,820$ & 121,270 & $20,629,473,390$ & $618,477,000$ & $7,276,200,000$ & $218,286,000$ & $28,742,4 ?$ \\
\hline $2008 / 2009$ & 124,703 & 124,703 & $4,988,096$ & 124,703 & $21,213,467,630$ & $630,685,300$ & $7,482,180,000$ & $224.465,400$ & $29,550,99$ \\
\hline $2009 / 2010$ & 128,231 & 128,231 & $5,129,261$ & 128,231 & $21,813,628,280$ & $659,078,100$ & $7,692,860,000$ & $230,815,800$ & $30,397,38$ \\
\hline $2010 / 2011$ & 131,861 & 131,861 & $5,274,419$ & 131,861 & $22,431,134,740$ & $672,491,100$ & $7,911,660,000$ & $237,349,800$ & $31,252,6 ?$ \\
\hline & total & & & & $141,137,804,100$ & $3,763,030,300$ & $49,780,560,000$ & $1,493,417,000$ & $196,174,8$ \\
\hline
\end{tabular}

*Approved Building Cost per Classroom by the Federal Government for UBE Commission, 2001

**Average costs of furniture for Teachers and Pupils from preliminary market survey

***Average cost for chalkboards from preliminary market survey

Source: (a) Researchers' Computation

(b) National Primary Education Commission, 2000, Abuja 
Additional cost of classrooms, furnitures and instruction board was not needed for the first three years of implementation as shown in Table 3. As from the fourth year however, when a total of $17,121,715$ pupils would have enrolled in primary 1 through primary 4 , additional $\$ 21,101,670,330$ would have been spent to adequately provide additional classrooms, instruction boards and; furniture for both teachers and students. By 2009/2010 school year when all the nine UBE classes would have been fully occupied, a total of $\$ 30,397,382,180$ would have been spent. The total cost of these facilities for the plan period would have been expected to be $\$ 196,174,811,400$ or on the average, $\$ 19,617,481,140$ per school year. When this cost that is seemingly high is added to the cost of projected total recurrent expenditures for the plan period, the cost implication of implementing the policy of free and compulsory school attendance for the plan period becomes clearly obvious as shown in table 4.

Table 4: $\quad$ Total Projected Cost of Implementing Free and Compulsory School Attendance Scheme, 2002-2011.

\begin{tabular}{rcclc}
\hline Year & $\begin{array}{c}\text { Projected } \\
\text { UBE School- } \\
\text { Going } \\
\text { Children }\end{array}$ & $\begin{array}{c}\text { Projected Total } \\
\text { Recurrent Cost } \\
\mathbf{( N )}\end{array}$ & $\begin{array}{c}\text { Projected Total } \\
\text { Capital Cost }(\mathbf{N})\end{array}$ & Total (N) \\
\hline $2001 / 2002$ & $4,102,949$ & $21,519,360,400$ & - & \\
$2002 / 2003$ & $8,322,012$ & $21,519,360,400$ & - & $21,519,360,400$ \\
$2003 / 2004$ & $12,660,474$ & $21,519,360,400$ & - & $21,519,360,400$ \\
$2004 / 2005$ & $17,121,715$ & $21,519,360,400$ & $21,101,670,300$ & $42,621,030,730$ \\
$2005 / 2006$ & $21,709,209$ & $27,219,489,530$ & $27,187,160,740$ & $54,406,650,270$ \\
$2006 / 2007$ & $26,426,529$ & $33,134,235,200$ & $27,951,527,590$ & $61,085,652,740$ \\
$2007 / 2008$ & $31,277,349$ & $39,126,216,350$ & $28,742,436,390$ & $67,958,652,740$ \\
$2008 / 2009$ & $36,265,447$ & $45,419,031,940$ & $29,550,998,330$ & $74,970,030,270$ \\
$2009 / 2010$ & $41,394,708$ & $51,900,342,810$ & $30,397,382,180$ & $82,297,724,990$ \\
$2010 / 2011$ & $46,669,127$ & $58,518,555,840$ & $31,252,635,640$ & $89,766,191,480$ \\
\hline \multicolumn{7}{c}{ Total } & $\mathbf{3 3 3 , 4 8 0 , 3 0 0 , 8 7 0}$ & $\mathbf{1 9 6 , 1 7 4 , 8 1 1 , 4 0 0}$ & $\mathbf{5 2 9 , 6 5 5 , 1 1 2 , 2 7 0}$ \\
\hline Source: Researchers' Computation & & &
\end{tabular}

The cost of implementing the scheme was the same for the first three years as shown in Table 4. The cost is seen to be almost a 100 percent increase in 2004/2005 school year because the first four classes in the UBE school scheme would have been expected to be adequately occupied. The increase continued steadily as the number of occupied classes in the UBE school scheme increased. In 2009/2010 school year when all the nine classes would have been occupied, total cost of implementing the scheme is projected to be $\$ 439,888,920,790$ while the total for the plan period is \$529.7 billion. Average cost of implementing the scheme annually during the period under investigation is seen to be about $\$ 52.97$ billion.

\section{Conclusion}

Education empowers people with knowledge and skill for useful and functional living in the society. When people are empowered educationally, they do not only live happily in the society but have superfluous victory over negative attitudes, laziness, illiteracy, disease, suspicion, poverty, fear, ruralization, wickedness, hatred, greed, poor temperament and the 
likes. The implementation of a free and compulsory school attendance scheme by government at this time is quite laudable. It will no doubt put Nigeria on the threshold of development, if adequate fund is made available for its sustenance. Consequent upon this, the paper projected the total cost of implementing the scheme for the next ten years to guide government's budgetary provision for the funding of basic education in Nigeria in the years ahead.

\section{Recommendations}

It is the contention of this paper that adequate funding of the UBE scheme will be possible if the following recommendations are accepted by government, the financier of the scheme. The recently approved 3\% of consolidated revenue by the National Assembly for the funding of UBE should as a matter of urgency be reviewed to the neighborhood of $10 \%$ so that more money will be made available to fund the scheme. Since the funding of education is a responsibility for all, the three tiers of government should in addition, be compelled through legislation to set aside a minimum of $26 \%$ of their annual budgets as recommended by UNESCO to fund education. Education tax of $2 \%$ paid by all registered companies in Nigeria should be reviewed upwards to $4 \%$ and evaders and defaulters sanctioned.

Members of the community, particularly PTA and NGOs should be encouraged to participate in the funding of UBE schools in the areas of building and/or equipping school libraries, laboratories, workshops, staff development etc. In this regards, the scope of the current effort of Shell Petroleum Development Company (SPDC) and Cadbury (Nig.) Education Community Projects be expanded and emulated by other multi-national companies.

Parent/Guardians of children not enrolled in schools should be persuaded and encouraged to enroll the children in school or prosecuted if they do otherwise.

\section{References}

Adewole, A. (2000). "Universal basic education: Aspects of meaning and purpose". A Paper Presented at the $15^{\text {th }}$ annual congress of the Nigeria Academy of Education. University of Benin, November 6-10.

Aghenta J.A. (2001). "Education planning: A turning point in education and development in Nigeria" $58^{\text {th }}$ Inaugural lecture series. University of Benin, Benin City.

Aiyepeku, T.F. (1989). 6-3-3-4 System of educationin Nigeria. Ibadan: NPS Education.

Akpa, G.O. (2014). Population growth and access to education in Nigeria: Making the millennium development goals real. A Paper Presented at the National Institute for Policy and Strategic Studies conference held at Kuru, Jos, Nigeria.

Chau, T.A. Ngoc (1960). Demographic aspects of educational planning. Paris: IIEP No. 9

Coombs, P.H. and Hallak, J. (1972). Managing educational costs. London: Oxford University Press Ltd. 
Federal Republic of Nigeria. (1993). Basic education for all in Nigeria by the year 2000. Lagos: Federal Ministry of Education.

Federal Republic of Nigeria (2004). National policy on education, Lagos: NERC Press.

Igbineweka, V.O. (2005). Analysis of wastage rates in Edo State secondary school system. An unpublished Ph.D Thesis, University of Benin, Benin City.

Igbineweka, V.O. and Ehiaguina, S.O. (2015). Teachers' perception of the factors responsible for attrition amongst teachers in public secondary schools in Edo Central education zone. Bепиe State University Journal of education, 15: August; 131-137.

Matsuura, K. (2000). "Education for all" A Paper Presented in his Capacity as UNESCO Director General at the World Education Forum held in Dakar, Senegal April 26-28 2000. Presentation at www2.unesco.org/wef/en-news/coverage-speech-jirhiro.shtm.

National Commission for Salary and Wages. (2014). National Minimum Wages and Salary Structure. Abuja: National Commission for Salary and Wages.

National Population Commission. (2013). "1991 population distribution by age and sex" Abstract of Statistics. Abuja; National Population Commission.

National Primary Education Commission. (NPEC, 1993). Manual for effective management of primary education in Nigeria. Kaduna, NPEC.

Nwaboku, N.C. and Abari, A.O. (2000). "Effective funding arrangements to ensure UBE success" A Paper Presented at an Education Conference, U.I., Ibadan.

Nwadiani, M. (2014), Education and transformational leadership in a tertiary learning environment. Prof. O.G. Oshodin in perspective. $6^{\text {th }}$ Faculty of Education distinguished Lecture series, University of Benin .

Nwadiani, M. (1996). Education in foreign countries: Lessons for policy planning and practice. Benin City: NSEP in Collaboration with Monose Amalgamates.

Nwagwu, C.C. (2001). Managing the challenges of the compulsory schooling aspect of the UBE programme. A Paper Presented at the $15^{\text {th }}$ Annual Conference of the Nigeria Academy of Education at Uniben. November 6-10.

Obanya P.A.I. (2000). "UBE as a necessary step". A Lead Paper Presented as the National Coordinator of Universal Basic Education (UBE) in a Conference/Workshop on UBE in Nigeria held at the Federal College of Education (Technical). Asaba. May 8.

Obanya P.A.I. (2000). "Sustainability, Stability and Continuity: The UBE response" A Lead Paper on UBE in Nigeria at University of Nigeria, Nsukka July 4-6. 
Omokhodion, J. O. (2000). "Universal basic education as an Instrument of development. The role of women education". A paper presented at the $15^{\text {th }}$ Annual Congress of the Nigerian Academy of Education. Uniben, Benin City: 6-10 November.

Philips, H. M. (1975). Basic education: A world challenge. London: John Wiley and Sons.

Universal Basic Education Commission. (2000). Proposed implementation blueprint for the universal basic education scheme. Abuja: UBEC.

UNDP (1998). Nigerian Human Development Report. Lagos: UNDP

UNESCO (1998). The state of education in Nigeria. Lagos Office: UNESCO

UNESCO (1995). Inter-Agency cooperation in basic education for all. Paris: UNESCO

UNESCO (1995). World education report. Paris: UNESCO

UNICEF (1999). Education for all: Making the right a reality. Paris: UNICEF

Woffensohn, J. D. (2000). "A time for action: Placing education at the core of development" A Paper Presented in his Capacity as President of the World Bank at the World Education Forum held in Dakar, Senegal, April 26-28 2000. Presentation at WEF, www2.unesco.org/wf/en-news/coverage-speech-wolfen.shtm.

World Education Forum. (2000). "Education for all: Meeting our collective commitment". A report of the Conference held in Dakar, Senegal 26-28 April presented at WEF, www2.unesco.org/wef/en-news/coverage-speech-wolfen.shtm. 